\title{
Pertumbuhan Dan Kadar Klorofil Tanaman Pakcoy (Brassica rapa L.) Terhadap Cekaman NaCl
}

\author{
V. Andriani \\ Fakultas Matematika dan Ilmu Pengetahuan Alam \\ Universitas PGRI Adi Buana Surabaya \\ Email: v.andriani@unipasby.ac.id
}

\begin{abstract}
Gravity salt is a soil condition with excessive amounts of soluble salt and adversely affecting plant growth. A number of agricultural crops are able to survive in areas with high salt. This study aims to determine the growth and content of packed chlorophyll packed $\mathrm{NaCl}$ at the beginning of the vegetative phase, and determine how optimal concentration in the growth of pakcoy. The research was conducted in experimental garden and basic laboratory of Faculty of Mathematics and Natural Sciences UNIPA Surabaya. The research design was using Random Random Complete with $\mathrm{NaCl}$ stress treatment variation. Variation of low $\mathrm{NaCl}$ stress treatment consisted of control watered with water (N0), initial $\mathrm{NaCl} 50 \mathrm{mM}+$ continued $150 \mathrm{mM}(\mathrm{N} 1)$, initial $\mathrm{NaCl} 75 \mathrm{mM}$ + continued $150 \mathrm{mM}(\mathrm{N} 2)$, initial $\mathrm{NaCl} 100$ $\mathrm{mM}+$ continued $150 \mathrm{mM}(\mathrm{N} 3)$, initial $\mathrm{NaCl} 125 \mathrm{mM}+$ continued $150 \mathrm{mM}(\mathrm{N} 4)$, and initial $\mathrm{NaCl} 150 \mathrm{mM}+$ continued $150 \mathrm{mM}$ (N5). Parameters observed were plant growth (plant height, leaf number, leaf width, and root length and biochemistry (leaf chlorophyll). The quantitative data obtained were analyzed using ANOVA and followed by DMRT test at $95 \%$ confidence level.The results showed that the $\mathrm{NaCl}$ stress treatment low at the beginning of the vegetative phase raising the height of the plant, the number of leaves, leaf width, root length and the highest leaf chlorophyll content in N1.
\end{abstract}

Keywords: $\mathrm{NaCl}$ stress, pakcoy, growth, chlorophyll, vegetative phase

\section{PENDAHULUAN}

Pakcoy tergolong dalam famili Brassicaceae. Tanaman ini dapat tumbuh di dataran rendah ataupun dataran tinggi dengan mendapatkan sinar matahari yang cukup (Edi dan Bobihoe, 2010). Tanaman ini banyak mengandung serat, vitamin $\mathrm{A}$, vitamin $\mathrm{B}$, vitamin $\mathrm{B} 2$, vitamin B6, vitamin C, fosfor, kalium, tembaga, magnesium, zat besi, dan protein. Kandungan tersebut berkhasiat untuk mencegah kanker, hipertensi, dan penyakit jantung.
Salinitas dapat disebabkan adanya perubahan iklim seperti cuaca yang sangat ekstrim (suhu menjadi sangat tinggi). Tingginya suhu dapat menyebabkan penguapan (evaporasi) berlangsung cepat dan meningkat. Peristiwa tersebut akan mengakibatkan akumulasi garam di dalam tanah. Perubahan suhu menjadi tinggi sangat mungkin terjadi di daerah dataran tinggi atau daerah pegunungan, sehingga daerah 
tersebut memiliki kadar garam yang tinggi (Setiawan et al., 2013). Indonesia merupakan negara tropis yang memiliki dua musim yaitu musim hujan dan musim kemarau. Pada waktu musim kemarau, curah hujan kurang, sehingga kurangnya air untuk melarutkan dan mencuci garam yang ada di dalam tanah. Drainase yang buruk juga menyebabkan evaporasi lebih besar daripada perkolasi yang merupakan faktor utama berlangsungnya proses salinisasi (Vangronsveld et al., 2009).

Salinitas pada tanah dapat berpengaruh pada proses pertumbuhan tanaman karena kandungan garam terlarut yang tinggi. Garam yang terkonsentrasi dalam tanah juga dapat berasal dari pupuk kimia yang terakumulasi. Salinitas pada tanah salah satu faktor abiotik utama yang mempengaruhi lahan irigasi pertanian secara global antara lain: lebih dari sekitar $40 \%$ dari lahan irigasi dan $20 \%$ dari lahan pertanian (Vangronsveld et al., 2009).

Garam $(\mathrm{NaCl})$ mempengaruhi pertumbuhan tanaman karena penyerapan garam secara berlebihan oleh tanaman dapat mengalami keracunan yang akan menyebankan penurunan penyerapan air (cekaman air) dan penurunan penyerapan unsur penting. Gejala awal yang diakibatkan oleh garam tanah yaitu daun berwarna lebih gelap daripada warna normal (hijau-kebiruan), ukuran daun lebih kecil dan jarak tangkai daun yang lebih pendek (UN-FAO, 2005; Pranasari, 2012). Dampak yang lebih ekstrim adalah daun menjadi klorosis (kuning) dan tepi daun mati mengering terbakar dan berwarna kecoklatan (UN-FAO, 2005).

\section{METODE PENELITIAN Rancangan Percobaan}

Rancangan penelitian yang digunakan adalah Rancangan Acak Lengkap dengan satu faktor, yaitu variasi konsentrasi $\mathrm{NaCl}(\mathrm{N} 1, \mathrm{~N} 2$, N3, N4 dan N5). Masing-masing perlakuan dengan 5 ulangan. Perlakuan penyiraman awal dilakukan sebanyak tiga kali dan penyiraman lanjutan tiga kali dengan konsentrasi tiap penyiraman sebanyak $500 \mathrm{ml}$.

\section{Persiapan medium tanah}

Proses penyemaian digunakan plastik diameter $3 \mathrm{~cm}$ sebanyak 30 buah yang diisi media tanam. Penanaman digunakan polybag $(30 \times 30 \mathrm{~cm})$ sebanyak 30 buah diisi media tanam $\pm 4 \mathrm{~kg}$ yang terdiri campuran tanahdengan pupuk organik (3:1) dan diaklimatisasi 1 minggu.

\section{Pemilihan dan penanaman bibit}

Biji pakcoy direndam menggunakan air selama 24 jam untuk merangsang perkecambahan dan penyeleksian bibit unggul. Biji terseleksi (bila direndam dalam air 
akan tenggelam) dan disemai pada plastik diameter $3 \mathrm{~cm}$ yang berisi tanah dan dibiarkan hingga biji berkecambah. Kecambah tersebut dipindahkan dalam polybag $(35 \times 35$ $\mathrm{cm}$ ) berisi media tanam, didiamkan selama 1 minggu untuk adaptasi. Selama adaptasi tanaman disirami air. Setiap perlakuan dibuat 5 ulangan dan setiap polybag berisi satu tanaman.

\section{Perlakuan cekaman $\mathrm{NaCl}$}

Perlakuan cekaman $\mathrm{NaCl}$ dimulai pada tanaman berumur 28, 33, 38, 43 dan 48 hari. Cekaman $\mathrm{NaCl}$ rendah (awal) diberikan sebanyak tiga kali pada tanaman berumur 28, 33, dan 38 hari dengan cara larutan $\mathrm{NaCl}$ disiramkan pada media tanam.

Perlakuan cekaman $\mathrm{NaCl}$ lebih tinggi (lanjutan) dilakukan sebanyak tiga kali pada tanaman berumur 43 dan 48 hari dengan cara sama seperti penyiraman $\mathrm{NaCl}$ rendah. Pada tanaman kontrol hanya disiram dengan air tanpa perlakuan garam rendah maupun tinggi. Penyiraman dilakukan setiap 5 hari sekali sebanyak $500 \mathrm{ml}$.

\section{Pengamatan dan Pengukuran Parameter}

Parameter yang diamati dan diukur meliputi parameter pertumbuhan dan biokimia.

\section{Parameter pertumbuhan}

Tinggi tanaman
Tinggi tanaman diukur mulai dari atas permukaan tanah hingga ujung daun tertinggi pada batang pokok. Pengukuran dilakukan seminggu sekali.

\section{Jumlah daun dan lebar daun}

Daun yang dihitung adalah daun yang muncul mulai dari ujung hingga pangkal batang dan lebar daun diukur pada daun yang terlebar.

\section{Pengukuran panjang akar}

Tanaman dicabut dengan hatihati dari polybag pada akhir pengamatan (umur 48 hari) dan diukur panjangnya mulai dari pangkal akar sampai ujung akar pada masing-masing perlakuan.

\section{Pengukuran kadar klorofil}

Analisis kandungan klorofil daun diukur dengan menggunakan metode Yoshida et al.(1976) saat tanaman berumur 48 hari. Sampel daun yang digunakan adalah daun ke-3 dari pucuk dengan ibu tulang daun dihilangkan. Daun ditimbang seberat 0,1 gram kemudian digerus dengan mortar dan dilarutkan dalam $10 \mathrm{ml}$ aseton $80 \%$.

Ekstrak disaring menggunakan kertas saring. Larutan hasil gerusan dimasukan kedalam tabung reaksi dan ditutup dengan aluminium foil. Untuk pengukuran, larutan klorofil dimasukan ke dalam kuvet diukur pada panjang gelombang 645 dan $663 \mathrm{~nm}$. 


\section{Analisis Data}

Hasil yang diperoleh berupa data kualitatif, Analisis data dengan menggunakan ANAVA, jika terdapat perbedaan dilanjutkan dengan DMRT.

\section{HASIL DAN PEMBAHASAN}

Faktor petumbuhan tanaman pakcoy yang diukur dalam penelitian ini antara lain tinggi tanaman, jumlah daun, dan panjang akar disajikan pada tabel 5.1.

Tabel 5.1 tinggi tanaman, jumlah daun, dan panjang akar tanaman pakcoy 5 minggu setelah perlakuan $\mathrm{NaCl}$ pada Fase Vegetatif.

\begin{tabular}{lcccccc}
\hline \multirow{2}{*}{ Parameter } & \multicolumn{5}{c}{ Perlakuan } \\
\cline { 2 - 7 } & N0 & N1 & N2 & N3 & N4 & N5 \\
\hline $\begin{array}{l}\text { Tinggi } \\
\text { tanaman } \\
\text { (cm) }\end{array}$ & $30,00^{\mathrm{a}}$ & $25,56^{\mathrm{b}}$ & $23,12^{\mathrm{c}}$ & $21,92^{\mathrm{d}}$ & $17,88^{\mathrm{e}}$ & $14,48^{\mathrm{f}}$ \\
\hline $\begin{array}{l}\text { Jumlah } \\
\text { daun }\end{array}$ & $12,00^{\mathrm{a}}$ & $11,00^{\mathrm{b}}$ & $9,00_{\mathrm{c}}$ & $8,00^{\mathrm{cd}}$ & $8,00^{\mathrm{ef}}$ & $7,00^{\mathrm{g}}$ \\
\hline $\begin{array}{l}\text { Lebar daun } \\
\text { (cm) }\end{array}$ & $9,28^{\mathrm{a}}$ & $9,28^{\mathrm{a}}$ & $7,72^{\mathrm{b}}$ & $5.00^{\mathrm{c}}$ & $4,62^{\mathrm{c}}$ & $3,58^{\mathrm{d}}$ \\
\hline $\begin{array}{l}\text { Panjang } \\
\text { akar }(\mathbf{c m})\end{array}$ & $5,96^{\mathrm{c}}$ & $11,30^{\mathrm{a}}$ & $6,46^{\mathrm{b}}$ & $6,68^{\mathrm{b}}$ & $5,20^{\mathrm{d}}$ & $2,72^{\mathrm{e}}$ \\
\hline
\end{tabular}

Keterangan: Angka yang didikuti huruf sama pada baris yang sama menunjukkan tidak ada beda nyata antar perlakuan dengan uji Duncan pada taraf signifikan 5\%.

Dari dan hasil pengukuran tinggi tanaman (tabel 5.1) secara statistik tinggi tanaman antara perlakuan dengan kontrol berbeda nyata. Kontrol memiliki tinggi tanaman yang dengan nilai rata-rata $30,0 \mathrm{~cm}$ dan tinggi terendah pada perlakuan. tinggi tanaman pakcoy antara perlakuan tertinggi terdapat pada perlakuan N5 yaitu $14,48 \mathrm{~cm}$. Tinggi pakcoy antara perlakuan tertinggi terdapat pada perlakuan N1 sebesar 25,56 cm dan terendah pada perlakuan N5 (tanaman kerdil). Pemberian dan peningkatan konsentrasi konsentrasi $\mathrm{NaCl}$ menyebabkan penambahan tinggi tanaman semakin terhambat pada fase vegetatif. Hal serupa terjadi pada tanaman Zea mayz dan Capsicum annuum (Suwignyo dkk., 2010; Pranasari dkk, 2012; Yiu et al., 2012). Pemberian konsentrasi garam tinggi pada fase vegetatif akan memberikan pengaruh yang lebih besar karena pesatnya pertumbuhan ada diawal pertumbuhan (Bintoro, 1989).

Daun merupakan salah satu organ tanaman yang dapat diamati secara langsung baik bentuk maupun jumlahnya. Daun merupakan tempat utama terjadinya fotosintesis serta jalur transpirasi. 
Pengamatan terhadap jumlah daun menunjukan bahwa seiring bertambahnya umur tanaman jumlah daun bertambah. Menurut Utaminingsih (2012), jumlah daun pada tanaman merupakan manivestasi hasil fotosintesis, karena pada fase vegetatif hasil fotosintesis dialokasikan untuk pertumbuhan termasuk pertumbuhan jumlah daun. Apabila tanaman kebutuhan air tercukupi, maka proses pembelahan dan pembentangan sel dapat berlangsung.

Berdasarkan Tabel 5.1, jumlah daun antar perlakuan dengan kontrol terdapat beda nyata. Jumlah daun kontrol lebih banyak dari pada tanaman perlakuan $\mathrm{NaCl}$. Hal ini dapat dipahami karena air yang tersedia dapat memenuhi kebutuhan tanaman untuk fotosintesis maupun pembelahan sel. Pada tanaman perlakuan N1 memiliki jumlah daun yang paling mendekati tanaman kontrol yaitu 12 daun. Hal ini mungkin karena cekaman $\mathrm{NaCl}$ yang diberikan pada awal fase vegetatif masih dalam konsentrasi yang rendah sehingga tanaman tidak terlalu terpegaruh. Selanjutnya diikuti tanaman $\mathrm{N} 2, \mathrm{~N} 3, \mathrm{~N} 4$ dan paling sedikit pada perlakuan N5 yaitu 7 daun. Hal ini menunjukan bahwa perlakuan konsentrasi $\mathrm{NaCl}$ rendah pada awal fase vegetatif dapat menghasilkan jumlah daun lebih banyak dibandingkan dengan perlakuan konsentrasi $\mathrm{NaCl}$ tinggi.
Semakin tinggi konsentrasi $\mathrm{NaCl}$ maka semakinsedikit jumlah daun yang dibentuk oleh tumbuhan.

Penurunan jumlah daun mungkin dikarenakan laju pembelahan sel primordia terhambat sehingga inisiasi daun tertunda. Levitt, (1980) menyatakankan, salah satu usaha tanaman untuk menyeimbangkan kadar air dan hara dalam tubuhnya akibat cekaman garam, dengan mengurangi jumlah daun untuk mengurangi transpirasi. Penurunan laju transpirasi mampu mencegah pertukaran ion $\mathrm{Na}^{+}$dan $\mathrm{Cl}^{-}$sehingga konsentrasi ion tersebut dalam jaringan dapat ditekan untuk mengurangi dampak negatif yang mungkin timbul jika akumulasi $\mathrm{Na}^{+}$ dan $\mathrm{Cl}^{-}$dalam jaringan cukup tinggi (Levitt, 1980). Selain itu juga tanaman mengutamakan energinya untuk mekanisme pertahanan terhadap cekaman $\mathrm{NaCl}$ dari pada pembentukan daun baru.

Pada Tabel 5.1, terlihat bahwa daun semakin menyempit seiring naiknya konsentrasi $\mathrm{NaCl}$.

Penyempitan daun guna mengurangi luas permukaan daun sehingga penguapan dapat dicegah. Semakin tinggi konsentrasi $\mathrm{NaCl}$ yang diberikan pada awal fase vegetatif maka pembentangan daun semakin terhambat. Terhambatnya perluasan daun disebabkan oleh adanya gejala keracunan $\mathrm{NaCl}$ (Suwignyo dkk., 2010) sehingga mengganggu proses diferensiasi sel pada titik tumbuh (Levitt, 1980) dan proses sintesis 
protein digunakan untuk mekanisme pertahana sehingga daun menjadi sempit (Neumann et al., 1988)

Selain memiliki daun yang sempit pucuk daun pakcoy menggulung, ujung daun berwarna coklat dan kering lalu gugur. Daun yang gugur efek cekaman garam akibat akumulasi $\mathrm{Cl}^{-}$pada daun (Alam, 1999). Hal ini diperkuat dengan pendapat tavakkoli et al. (2010) ketika terjadi cekaman garam, awal tanaman akan mengalami fase stress osmotic yang akan menyebabkan terjadinya perlambatan kemunculan daun, menghambat perluasan daun dan merangsang senese daun akibat akumulasi ion toksik yang berlebihan. Sense daun terjadi karena adanya pertransferan unsur $(\mathrm{N}, \mathrm{P}, \mathrm{K})$ kedaun yang lebih muda.

Hasil pengukuran panjang akar nilai tertinggi dengan jumlah akar banyak terdapat pada Kontrol $\mathrm{N} 1$ yaitu $11,3 \mathrm{~cm}$ dan terendah pada perlakuan N5 yaitu $2,72 \mathrm{~cm}$. Dibandingkan dengan kontrol panjang akar N1, N2, N3 lebih panjang dengan jumlah akar lebih sedikit. Hal ini menunjukan bahwa perlakuan N1, N2, N3 tidak menghambat proses pemanjangan akar justru memperpanjang akar dan ini diduga adaptasi tanaman pakcoy terhadap cekaman $\mathrm{NaCl}$. Pertumbuhan batang dan daun terhambat pada saat kondisi tercekam garam namun tidak demikian dengan pertumbuhan akar
(Suwignyo et al., 2010). Berbeda dengan hasil pengukuran panjang akar pada perlakuan N4 dan N5, akar lebih pendek seiring dengan tingginya $\mathrm{NaCl}$ awal yang diberikan. Penurunan ini memperlihatkan mulai terhambatnya pembentukan akar akibat cekaman $\mathrm{NaCl}$.

Semakin tinggi cekaman $\mathrm{NaCl}$ maka akar semakin pendek kecuali perlakuan N1, N2, dan N3. Hal ini berhubungan dengan peran akar dalam penyerapan air selama masa pertumbuhan, yaitu menentukan kelancaran proses fotosintesis untuk perkembangan daun, batang, bunga dan buah. Peran akar menjadi bertambah penting pada kondisi tanah tercekam $\mathrm{NaCl}$ yang menyebabkan berkurangnya penyerapan air. Salah satu upaya tanaman untuk mencukupi kebutuhan air dalam tubuhnya yaitu melalui peningkatan panjang akar untuk memperluas bidang penyerapan air. Dalam kondisi tanaman kekurangan air akibat cekaman $\mathrm{NaCl}$, alokasi hasil fotosintesis akan lebih banyak dialihkan keakar untuk memperpanjang akar dan membentuk bulu akar sebagai bentuk adaptasi terhadap cekaman $\mathrm{NaCl}$. Kelebihan garam pada tanaman N4 dan N5 membuat akar lebih pendek dengan ukuran diameter akar kecil, hal ini mungkin disebabkan oleh penghambatan pada proses pemanjangan dan pembelahan sel kesamping. 
Garam

mungkin mempengaruhi pertumbuhan secara langsung dan tidak langsung dengan menurunnya jumlah fotosintat, air atau faktor-faktor tumbuh yang mencapai titik tumbuh. Jumlah fotosintat yang mencapai titik tumbuh mungkin berkurang karena penghambatan fotosintesis yang disebabkan oleh menutupnya stomata (Shannon, 1993) atau pengaruh langsung dari garam pada organ fotosintetik. Transpot fotosintat pada floem juga dihambat, selanjutnya dikatakan bahwa ion dan garam dapat merusak sel yang tumbuh secara tidak langsung dengan cara penghilangan substansi esensial (Pradnyawathi, 1999).

Selama pertumbuhan vegetatif, tanaman berusaha untuk menjaga sistem perakaran yang akan mendukung tanaman dan penyediaan air dan hara (Shannon, 1993). Cekaman $\mathrm{NaCl}$ mempengaruhi keseimbangan ini khususnya dengan penurunan pertumbuhan vegetatif atas yang lebih dibandingkan pertumbuhan akar (Pradnyawathi, 1999). Harjadi dan Yahya (1988) menyatakan bahwa, meningkatnya nisbah akar tajuk diduga memperbaiki keseimbangan dengan mempertahankan kemampuan menyerap air bersamaan dengan itu mengurangi transpirasi.

\subsection{Kadar Klorofil}

Hasil pengamatan terhadap kadar klorofil total disajikan pada tabel 5.2. tanaman control memiliki kadar klorofil tertinggi.

Tabel 5.2 Kadar Klorofil a,b, dan Kadar Klorofil Total (mg/g) Daun Pakcoy 5 Minggu Setelah Perlakuan $\mathrm{NaCl}$ pada Fase Vegetatif.

\begin{tabular}{cccc}
\hline Perlakuan & \multicolumn{3}{c}{ Kadar } \\
\cline { 2 - 4 } & Klorofil a & Klorofil b & Klorofil Total \\
\hline N0 & $4,19^{\mathrm{a}}$ & $2,11^{\mathrm{a}}$ & $6,30^{\mathrm{a}}$ \\
\hline $\mathbf{N 1}$ & $4,06^{\mathrm{a}}$ & $1,89^{\mathrm{b}}$ & $5,95^{\mathrm{b}}$ \\
\hline $\mathbf{N} 2$ & $3.04^{\mathrm{b}}$ & $1,55^{\mathrm{c}}$ & $4,59^{\mathrm{c}}$ \\
\hline N3 & $2,86^{\mathrm{b}}$ & $1,50^{\mathrm{cd}}$ & $4,36^{\mathrm{cd}}$ \\
\hline N4 & $2,82^{\mathrm{b}}$ & $1,40^{\mathrm{d}}$ & $4,22^{\mathrm{d}}$ \\
\hline N5 & $2,28^{\mathrm{c}}$ & $1,24^{\mathrm{e}}$ & $3,52^{\mathrm{e}}$ \\
\hline
\end{tabular}

Keterangan: Angka yang didikuti huruf sama pada baris yang sama menunjukkan tidak ada beda nyata antar perlakuan dengan uji Duncan pada taraf signifikan 5\%. 
Menurut Boudsocq et al., (2005) dan

ketersediaan Basuki

(2014), $\mathrm{NaCl}$ dengan konsentrasi yang tinggi pada tanah menyebabkan berkurangnya ketersediaan air dan unsur hara yang dibutuhkan tanaman. Rendahnya potensial air tanah memacu air keluar dari jaringan sehingga tumbuhan kehilangan tekanan turgor dan potensial air daun menurun. Hal ini sependapat dengan Djukri (2009), bahwa berlimpahnya $\mathrm{Na}^{+}$dan $\mathrm{Cl}^{-}$ menyebabkan ketidakseimbangan ion yang berdampak pada terganggunya aktifitas tubuh tumbuhan.

Unsur hara yang dibutuhkan dalam pembentukan klorofil adalah $\mathrm{Mg}, \mathrm{N}$ dan $\mathrm{Fe}$ (Aronoff, 1950; Utaminingsih, 2012; Yiu et al., 2012). Kondisi tanah kekurangan air akibat tingginya $\mathrm{NaCl}$ di daerah perakaran menyebabkan $\mathrm{Mg}$ dan $\mathrm{Fe}$ akan berada dalam kondisi terikat atau tidak tersedia bagi tanaman, selain itu adanya kompetisi antara penyerapan $\mathrm{Mg}$ dan $\mathrm{Na}$ yang menyebabkan kandungan $\mathrm{Mg}$ menurun dan pembentukan klorofil daun akan terganggu dan struktur kloroplas akan mengalami disintegrasi yang berakibat rendahnya kadar klorofil (Harjadi dan Yahya, 1988, Utaminingsih, 2012).

$\mathrm{Mg}$ dan $\mathrm{N}$ merupakan unsur yang membentuk struktur klorofil, sementara $\mathrm{Fe}$ dibutuhkan sebagai kofaktor enzim yang penting untuk pembentukan klorofil. Kurangnya unsur $\mathrm{Fe}$ menyebabkan penurunan aktivitas enzim yang berperan dalam konversi protoporphyrin menjadi klorofil, sedangkan kurangnya $\mathrm{Mg}$ dan $\mathrm{N}$ menyebabkan penurunan fungsi klorofil (Aronoff, 1950; Marsh et al., 1963). Menurut Lisar et al., (2014), cekaman kekeringan menghambat sintesis klorofil dengan cara menghambat pembentukan prekursor klorofil yakni 5aminolevuliniuc acid (ALA). Dalam kondisi tercekam garam, aktivitas $\mathrm{Mg}^{2+}$-ATPase dan $\mathrm{Ca}^{2+}$-ATPase tertekan sehingga menyebabkan berkurangnya sintesis ATP di daun gandum. Selain itu tertekannya sintesis ATP merusak Photosistem II (PSII) dan asimilasi CO (Zeng et al., 2009).

Penurunan kandungan $\mathrm{Mg}$ akibat tingginya penyerapan $\mathrm{NaCl}$ terjadi juga pada daun alpukat dan menyebabkan penurunan kandungan klorofil pada daun Zea mays (Suwignyo dkk., 2010), pada barley (Tavakkoli et al., 2011), dan pada daun Capsicum annuum L. (Yiu et.al., 2012). 
DAFTAR PUSTAKA

Alam, M.S. 1999. Nutrient Uptake by Plants Under Stress Conditions. Pakistan, Nuclear Institute of Agriculture: 295-299.

Bintoro, M. H. 1989. Toleransi Tanaman Jagung Terhadap Salinitas.

Program Pascasarjana IPB Bogor.

Djukri, 2009. Cekaman Salinitas terhadap Pertumbuhan Tanaman. Prosiding. Seminar Nasional Penelitian, Pendidikan dan Penerapan MIPA. 16 Mei 2009, Yogyakarta

Edi S. dan J. Bobihoe. 2010. Budidaya Tanaman sayuran. BPTP, Jambi.

Harjadi S.S., dan Yahya, S. 1988. Fisiologi Stress Lingkungan. Bogor: IPB.

Lisar, S.Y.S., Motafakkerazad, R., Hossain, M.M., and Rahman, I.M.M. 2012. Water Stress in Plants: Causes, Effects and Responses. In: Rahman, I.M.M \& Hasegawa, H. Water Stress, InTech, Croatia, p: 1-14.

Levitt, J. 1980. Response of Plant to Environmental Stress. Academic Press. New York.

Marschner, H. 1986. Mineral Nutrion of Higher Plants. London: Academic Press. Marsh, J.H.V., Evans, H.J., and Matrone. 1963. Investigation of The Role of Iron in Chlorophyll Metabolism: I. Effect of Iron Deficiency on Chlorophyll and Heme Content and on The Activities of Certain Enzymes in Leaves. Plant Physiology, 38 (6) : 632638.

Pradnyawathi, $\quad$ N.L.M. 1999. Ketahanan Tanaman Kedelai Terhadap Cekaman Salinitas pada Berbagai Stadia Pertumbuhan. Agronomi Ilmu Pertanian UGM: Tesis.

Pranasari, R.A., Nurhidayati, T., dan Purwani, K.I. 2012. Persaingan Tanaman Jagung (Zea mays) dan Rumput Teki (Cyperus rotundus) pada Pengaruh Cekaman Garam ( $\mathrm{NaCl})$. Jurnal Sains dan Seni ITS, 1 (1): 2301-928X.

Setiawan T dan Shiddieq D. 2013. Pengaruh Cekaman Kurang Air terhadap Beberapa Karakter Fisiologis Tanaman Nilam (Pogostemon cablin Benth). Jurnal Littri 19 (3) Hlm.108-116 ISSN 08538212.

Shannon, M.C. 1993. Adaptation of Plant Salinity. Advance in 
Agronomy. Deleware Acadmic Press. San Diego. Suwignyo dkk, R.A., Renih, H., dan Mardiyanto. 2010. Induced Salt Tolerance of Maize Crop by Low Salinity Pretreatment. Fakultas Pertanian Unsri: Journal Agrivigor, 10 (1) : 73-83.

Tavakkoli, E., Fatehi, F., Coventry, S., Rengasamy, P., and McDonald, G.K. 2011. Additive Effects of $\mathrm{Na}^{+}$and $\mathrm{Cl}$ Ions on Barley Growth Under Salinity Stress. Journal of Experimental Botany, 62 (6): 2189-2203.

United Nations Food and Agriculture Organization (UN-FAO). 2005. $20 \mathrm{Hal}$ untuk Diketahui Tentang Dampak Air Laut pada Lahan Pertanian. Diakses tanggal 17 Juni 2014 melalui :

www.UNFAO.org/ag/tsuna mi/docs/20_things_on_sali nity bahasa.p.

Utaminingsih. 2012. Mikrosporogenesis Cabai Merah Besar (Capsicum aпnиuтL.) Akibat Cekaman Kekeringan. Fakultas Biologi UGM: Tesis.
Vangronsveld J, Herzig R, Weyens $\mathrm{N}$, Boulet J, Adriaensen K, Ruttens A, Thewys T, Vassilev A, Meers E, Nehnevajova $E$ et al. (2009). Phytoremediation of contaminated soil and groundwater: lessons from the field. Environ Sci Pollut Res. 16:765-794.

Yiu, J.C, Tseng, M.J., Liu, C.W., and Kuo, C.T. 2012. Modulation of $\mathrm{NaCl}$ Stress in Capsicum annuum $\mathrm{L}$. Seedlings by Catechin. Scientia Holticulturae, 134: 200-209.

Zheng, C., Jiang, D., Liu, F., Dai, R., Jing, Q., and Cao, W. 2009. Effects of Salt and Waterlogging Stresses and Their Combinsation on Leaf Photosynthesis, Chloroplast ATP Synthesis, and Antioxidant Capacity in Weat. Plant Sci, 176: 575-582. 